\title{
The Effect of Collaborative Prewriting Discussions on L2 Writing Development and Learners' Identity Construction
}

\author{
Golnar Mazdayasna* \\ Assistant Professor of Applied Linguistics, \\ Yazd University, Yazd, Iran \\ Amin Zaini \\ MA in TEFL, Yazd University, Yazd, Iran
}

Received 8 January 2015; revised 3 July 2015; accepted 16 August 2015

\begin{abstract}
The current study investigated the effect of collaborative prewriting activities on learners' identity construction and L2 writing development. To this end, 43 sophomore upper-intermediate university students majoring in Teaching English as a Foreign Language at an Iranian university who had enrolled in a course called Advanced Writing were randomly divided into two experimental groups (groups A and B) and one control group (group C). While the students in group A were involved in group activities, the students in group B were engaged in pair activities. The students in control group (group C) worked individually. As a pre-test, a penand-paper writing task was given to all the students at the beginning of the semester. During the semester, all the participants were exposed to the same materials and were taught by the same teacher for one semester. The only difference was the type of activities in which the participants were engaged. At the end of one semester, a pen-and-paper writing task was given to all the three groups. The findings of the post-test revealed that all the students could significantly
\end{abstract}

*Corresponding author: Department of English Language \& Literature, Faculty of Languages \& Literature, Yazd University, Safayeh, Pajuhesh Intersection, Yazd, Iran.

Email address: gmazdayasna@yazd.ac.ir 
improve their writing skills. Nevertheless, the students in group B significantly outperformed their counterparts. Most importantly, the results of identity analysis showed that the students in group A used authorial plural pronouns along with adjectives more frequently. The findings of this study confirmed two issues: first, the significant efficacy of prewriting activities were confirmed at the end of the semester. Second, each type of prewriting activity could affect the learners' identity construction.

Keywords: Prewriting discussions; Collaborative activities; Writing skills; Identity; Collective identity; Individualistic identity; Authoritative identity

\section{Introduction}

Collaborative writing activity is defined as a task in which a group of learners are engaged in collaborative writing tasks and, finally, submit one final written text (see Swain, 2001). Grouping has been a common trend in teaching and learning since the beginning of the 19th century. There are different viewpoints regarding the effects of grouping in writing classes. One group of scholars (see Galton, 1990; Galton, Hargreaves, Comber, Wall \& Pell, 1999) are pessimistic about students working in groups. The results of their studies revealed that the outcome of working in groups led to failure and inhibited learning.

On the other hand, the second group of scholars (see, Fernandez Dobao, 2012; Shehadeh, 2011) believe that group activities ameliorate the process of learning. They believe that collaborative activities in writing classes and engaging learners in group accomplishments have proved to be effective (see, Shehadeh, 2011). In this light, Shehadeh (2011) highlighted the critical role of collaborative group activities in writing classes. Fernandez Dobao (2012) also examined the efficacy of collaborative writing tasks by involving three different sets of learners, namely working in groups of four learners, pairs, and individuals. The results of the study revealed that learners who were engaged in group activities made more languagerelated episodes. Likewise, they achieved a higher proportion of appropriate resolved, language -related episodes than their counterparts who worked in pairs. Moreover, they produced more accurate texts in comparison to those students who wrote individually or worked in pairs. Most importantly, when students work in groups, they benefit from positive peer interaction. Positive peer interaction 
includes activities such as sharing, helping, and collaborating during the process of learning (see Lamb-Parker et al., 2008 Lamb-Parker, LeBuffe, Powell, \& Halpern, 2008). Similarly, by working together, children coordinate ideas and build on each other's knowledge and experience to promote learning (see Palermo \& Mikulski, 2014).

Similarly, the role of pair work has been an attention-grabbing issue for scholars. The effect of pair activities on learners' writing skills has been effective in comparison to individual activities in the literature. For instance, Storch (2005) conducted an action research in which twenty-three adult ESL students were given a choice to write in pairs or individually. The results revealed that students who worked in pairs produced shorter but higher-quality texts in terms of task fulfilment, grammatical accuracy, and complexity. In a similar vein, Kim (2008) compared the effectiveness of collaborative and individual tasks on the acquisition of L2 vocabulary by Korean learners. The effect of dictoglass tasks was examined on pairs and individuals. The results indicated that there was no significant difference between pairs who were engaged in collaborative tasks and individuals in the number of Language Related Episodes (LREs); however, pairs performed significantly better on the vocabulary tests. In another study, Fernandez Dobao and Blum (2013) compared the effectiveness of pair and group activities on collaborative writing tasks in comparison to individual activities. The results obtained from questionnaires revealed that learners involved in both group and pair activities had positive attitudes toward the above-mentioned activities they were engaged in. Accordingly, most students recognized the positive impact of working with a peer on different aspects of language learning and improving their writing skills.

Beyond the possible effects of the above-mentioned activities on learners' writing performances, learners' writing texts as outputs are important since they provide teachers with an opportunity to analyze and understand the identity of their students. Consequently, there is a relationship between different types of activities (as mentioned above) as well as written language and, subsequently, there is a kind of relationship between identity and written language as it enables the researchers of this study to understand the identity of the writers. 
Norton (2000) believes that an individual's identity can be understood through identifying an individual's investment. By investment, Norton means an individual's instrumental and integrative motivation. Mejia (2002) asserts that language is a symbolic source signifying linguistic skills, cultural awareness, and particular abilities. It helps individuals to have an access to different social, educational, and factual assets. Most importantly, using language is beyond merely exchanging information. It is about forming and differentiating one's identities. Therefore, communication via written language as a mode can help educators to understand specific kinds of identity that students construct in an educational environment.

Similarly, Miller (2003) extended this idea to the field of second/foreign language learning. He believes using language is beyond exchanging information. Learners reveal their identity when they are involved in communication. Moreover, Correa (2011) suggested that the relationship between writing and identity are not pre-formulated; on the contrary, they are continuously being constructed. The integrationist approach helps us understand this complexity more deeply and broaden our view of the interrelationship between writing and identity.

Likewise, Hua (2007) asserts that writers in all genres present themselves through their writing samples, where the social-cultural background influences writers' thoughts and arguments which will be written on papers and form a final product. In addition, by choosing certain rhetorical patterns, writers represent themselves. This implies that a written text is an opportunity for researchers to understand the identity of writers (see Ivanic 1999). This study relies on Ivanic's (1999, p.23) framework which claims that writer's identity is built in potentials for "self-hood". This potential is available in the sociocultural context of writing. She proposed that there are four aspects of existing identity in writing including autobiographical self, discoursal self, authorial self, and possibilities for selfhood.

'Autobiographical self' is affected by the writer's life-history, while 'discoursal self' is the image or voice the writer projects in a text. The 'authorial self' is concerned with writer's imposition and entrance into the text and the demand of the responsibilities for its content. Finally, "possibilities for selfhood in the sociocultural and educational environments" (Ivanic 1999, p.27) is an abstract notion of writer's identity involving socially available possibilities for selfhood. It takes into consideration those possibilities which are available within a 
sociocultural as well as institutional context and the way these possibilities shape up or constrain individual acts of writing. Accordingly, by analyzing video-based conversations and using ethnographic methods, Olinger (2011) found that the writers represent an array of identities in the class. Accordingly, through an analysis of stance, which allow writers to take up positions and express judgments (see Hyland, 2000), the researchers specified how interactions in the language classes construct discoursal identities.

To date, a number of researchers have conducted studies on the effectiveness of different types of activities, namely group and pair engagements as well as individual activities; however, few studies have compared the effectiveness of group activities and pair work. Therefore, this study aimed to compare the effectiveness of group activities, pair work, and individual activities on the development of EFL writing skills. The secondary aim of this study was to understand and analyze identity construction of different EFL learners under the influence of group, pair, and individual works.

\section{Research questions}

The current study addressed the following research questions:

(1) Which type of activity (group, pair, and individual) is more successful to help learners improve their writing skills effectively?

(2) How do learners in different groups construct various identities based on different types of activities in which they are involved?

\section{Methodology}

\section{Participants}

The current study was conducted at one of the Iranian State universities in the academic year 2014-2015. All the participants were majoring in Teaching English as a Foreign Language and they had enrolled in 'Advanced Writing' course. At the 
beginning of the study, all the students took Oxford Quick Placement Test. Accordingly, forty three students at Upper-intermediate level of English language proficiency participated in this study. At the next stage, they were randomly divided into two experimental groups (Group A \& B) and one control group (Group C).

\section{Procedure}

During the semester, all the participants received instruction from the EFL teacher (one of the researchers of the study who was the same person for all the three groups). The only difference was the type of activities in which the students were engaged. While, 15 students in group A were involved in group activities, 14 students in group B had to compose and write in pairs. But, 14 students in group C were asked to write individually. The topic assigned to all the three groups on the pre-test and post-test was as follows:

Students mostly like one of the teachers more than others. Explain why one particular teacher in your life was so special.

The students were asked to write about this topic because nearly all students had experienced such a feeling in their real lives. Second, students had a wide range of options to write about this topic. Students can describe their own personal experiences and, probably, write an anecdote.

The required data for this study were collected in this way: all the participants in the three groups received instruction from the same EFL teacher who utilized the same book in the three classes. They were given instruction on issues, such as writing a topic sentence, narrowing down a broad subject into a topic sentence; in addition, students were asked to use diagrams in order to analyze how supporting material (examples, details, anecdotes) relates directly to the topic sentence and thus creates unity within the paragraph. Moreover, the students were familiarized with rhetorical patterns most commonly found in expository writing (enumeration, process, chronology, cause and effect, and comparison and contrast). Most importantly, the students were instructed to write a logical and coherent paragraph.

The only difference among the two experimental groups and one control group was the class activities which they had to perform. The students in group $A$ 
were asked to work in group activities. Because all of them were at the same level of English language proficiency, the teacher randomly divided the students into one group of 3 members as well as three groups of 4 members. After receiving instructions on each session, the students were engaged in group activities. Each single group had to write one assignment as a final task during the class time on each session. Likewise, students in each group were supposed to write a final task as their homework and submit it to the teacher on the following session. They were recommended to meet each other at a certain time in the study room located in the central library. Based on the rules and regulations of the university, the students were allowed to study and talk together at collective study halls. A few students reported that they felt more comfortable to collect relevant information elsewhere, such as at city public library or university campus. They were free to choose their own place of meeting. The teacher collected their writing tasks on each session and provided them with feedback and comments. On the following session, the teacher returned their corrected writing tasks and the students submitted their writing assignments which students had to write as homework.

The students in the second experimental group (group B) received the same instruction. However, they were not engaged in group activities. On the contrary, they were asked to compose and write their tasks in pairs. Since the students were at the same level of English language proficiency, the teacher allowed them to choose their pairs on their own. Each pair of students had to compose and write one topic in class and submit it to the teacher at the end of the session. In addition, they were given one assignment as their homework. The teacher provided feedback on their writing performances and returned their writing tasks on the following session. Furthermore, the students submitted their homework to the teacher to receive feedback and comments.

Finally, the students in the control group (group C) were asked to compose and write individually. At the end of each session, the students had to submit their writing tasks individually; in addition, one topic was assigned as homework which the students had to submit on the following session. The teacher corrected their writing tasks and provided the students with comments and feedback on their writing tasks. On the next session, the teacher returned the writing tasks and the 
students, subsequently, submitted their homework to the teacher to receive feedback and comments.

To sum up, all the students in the experimental and control groups had to write one topic in class and one writing task as homework. The teacher provided feedback and comments on their writing tasks. However, the only difference was experiencing different types of activities namely group, pair, and individual ones. At the end of the semester, the students were given the above-mentioned topic to write about as the post-test activity. The results of data analysis regarding both identity analysis (from the viewpoint of Ivanic, 1999) and writing skills are elaborated in the following section.

\section{Results}

\section{Writing tasks}

The writing samples from the pre-test and post-test were examined and graded by the researchers. In the current study, Jacobs, Zinkgarf, Wormuth, Hartfiel and Hughey's (1981) ESL composition profile was used as a rating checklist. This construct is comprised of five measures namely content $(30 \%)$, organization (20\%), vocabulary (20\%), language use (25\%), and mechanics (5\%). Accordingly, each writing sample was marked and given a score out of 100 based on the aforementioned features. The raw data obtained from the pretest was given to SPSS and the subsequent results revealed that all the participants were at the same level of proficiency. As Table 1 displays, there was no significant difference among the students in three mentioned groups based on ANOVA results. 
Table 1

The results of pre-test writing tasks

\begin{tabular}{llrrrrr}
\hline $\begin{array}{l}\text { (I) } \\
\text { Groups }\end{array}$ & $\begin{array}{l}\text { (J) } \\
\text { Groups }\end{array}$ & $\begin{array}{c}\text { Mean } \\
\text { Difference } \\
(\mathrm{I}-\mathrm{J})\end{array}$ & \multicolumn{1}{c}{$\begin{array}{c}\text { Std. } \\
\text { Error }\end{array}$} & & Sig. & \multicolumn{2}{c}{$\begin{array}{c}\text { 95\% Confidence } \\
\text { Interval }\end{array}$} \\
\cline { 3 - 7 } & & & & $\begin{array}{c}\text { Lower } \\
\text { Bound }\end{array}$ & $\begin{array}{c}\text { Upper } \\
\text { Bound }\end{array}$ \\
\hline \multirow{2}{*}{ Group A A } & Group B & .076 & .562 & .990 & -1.29 & 1.44 \\
\cline { 2 - 7 } & Group C & .005 & .562 & 1.000 & -1.36 & 1.37 \\
\hline \multirow{2}{*}{ Group B B } & Group A & -.076 & .562 & .990 & -1.44 & 1.29 \\
\cline { 2 - 7 } & Group C & -.071 & .572 & .991 & -1.46 & 1.32 \\
\hline \multirow{2}{*}{ Group C C Group A } & -.005 & .562 & 1.000 & -1.37 & 1.36 \\
\cline { 2 - 8 } & Group B & .071 & .572 & .991 & -1.32 & 1.46 \\
\hline
\end{tabular}

Next, a comparison of the writing tasks of the students on the pre-test and posttest was conducted. The results illustrated in Table 2 revealed that all the students in the experimental and control could significantly improved their writing skills at the end of the semester. These measures were obtained from SPSS after conducting paired samples t-tests as follows: Group A ( $\mathrm{p}=.000)$, Group B ( $\mathrm{p}=.000)$, and Group $\mathrm{C}(\mathrm{p}=.000)$. The findings revealed that all the aforementioned types of activities were effective.

Table 2

Paired samples t-tests on writing tasks

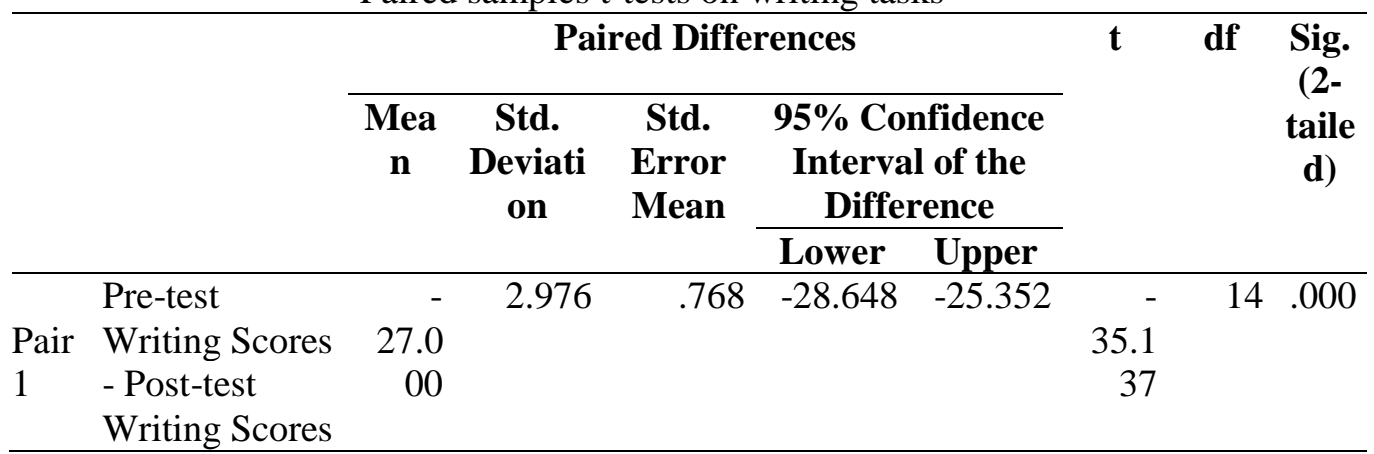




\begin{tabular}{llrlrrrrrr}
\hline & Pre-test & - & 3.647 & .975 & -36.034 & -31.823 & - & 13 & .000 \\
Pair & Writing Scores & 33.9 & & & & & 34.8 & & \\
2 & - Post-test & 29 & & & & & 07 & & \\
& Writing Scores & & & & & & & & \\
\hline \multirow{2}{*}{ Pair } & Pre-test & - & 2.786 & .745 & -21.537 & -18.320 & - & 13 & .000 \\
3 & Writing Scores & 19.9 & & & & & 26.7 & & \\
& - Post-test & 29 & & & & & 61 & & \\
\hline
\end{tabular}

Nevertheless, the results of ANOVA revealed that some activities were found to be more effective in comparison with other activities. As Table 3 displays, students in group B remarkably improved their writing skills in comparison with students in group A $(\mathrm{p}=.000)$ and Group $\mathrm{C}(\mathrm{p}=.000)$. Students in group A could significantly improve their writing skills in comparison to students in group $\mathrm{C}$ $(\mathrm{p}=.000)$. The results from between-group analysis indicated that pair activities were more effective and helped students to improve their writing skills in comparison with individual and group activities. In subsequent turn, group activities were shown to be more effective than individual activities (Table 3).

Table 3

The results of post-test writing tasks

\begin{tabular}{|c|c|c|c|c|c|c|}
\hline \multirow{2}{*}{$\begin{array}{l}\text { (I) } \\
\text { Groups }\end{array}$} & \multirow{2}{*}{$\begin{array}{l}(\mathbf{J}) \\
\text { Groups }\end{array}$} & \multirow{2}{*}{$\begin{array}{c}\text { Mean } \\
\text { Difference } \\
\text { (I-J) }\end{array}$} & \multirow{2}{*}{$\begin{array}{l}\text { Std. } \\
\text { Error }\end{array}$} & \multirow[t]{2}{*}{ Sig. } & \multicolumn{2}{|c|}{ 95\% Confidence Interval } \\
\hline & & & & & $\begin{array}{l}\text { Lower } \\
\text { Bound }\end{array}$ & $\begin{array}{l}\text { Upper } \\
\text { Bound }\end{array}$ \\
\hline \multirow{2}{*}{ Group A } & Group B & $-6.852^{*}$ & 1.095 & .000 & -9.52 & -4.19 \\
\hline & Group C & $7.076^{*}$ & 1.095 & .000 & 4.41 & 9.74 \\
\hline \multirow{2}{*}{ Group B } & Group A & $6.852^{*}$ & 1.095 & .000 & 4.19 & 9.52 \\
\hline & Group C & $13.929^{*}$ & 1.113 & .000 & 11.22 & 16.64 \\
\hline \multirow{2}{*}{ Group C } & Group A & $-7.076^{*}$ & 1.095 & .000 & -9.74 & -4.41 \\
\hline & Group B & $-13.929^{*}$ & 1.113 & .000 & -16.64 & -11.22 \\
\hline
\end{tabular}




\section{Identity analysis}

In addition, learner writers' identities were analyzed through representation of self and the manner in which they revealed their identities. To this end, the researchers underlined all the pronouns used by each student on the pre-test and post-test writing tasks separately. Next, first-person pronouns were tallied and divided into two parts, namely singular first person pronouns and plural first person pronouns. Singular first person pronouns included the following ones namely $I, m e$, and mine. Moreover, possessive adjectives (my) were also tallied. First-person plural pronouns involved we, us, ours. The researchers also counted our as a possessive adjective. In this manner, the researchers analyzed the number of learner writers displaying their authorities. Moreover, the effect of different types of activities on identity construction of the learners was also investigated. An attempt was made to examine the possible relationships among group, pair, and individual activities in terms of using singular/plural first person pronouns.

The results obtained from the analysis of the pre-test writing tasks (MANOVA) revealed that there was no significant difference between the number of singular and plural pronouns that students used in their writing performances. There was no significant difference among the writing tasks of the students in different groups, namely $\mathrm{A}$ and $\mathrm{B}(\mathrm{p}=.167), \mathrm{A}$ and $\mathrm{C}(\mathrm{p}=.508)$, and $\mathrm{B}$ and $\mathrm{C}(\mathrm{p}=.472)$ regarding the number of first person singular pronouns and possessive adjectives which the participants had used in their pre-test writing tasks (Table 4). Similarly, there was no significant difference among the performances of the students in different groups regarding the number of first person plural pronouns and adjectives which the participants had used in their pre-test writing tasks (Table 5). 
Table 4

The use of first person singular pronouns and possessive adjectives

\begin{tabular}{|c|c|c|c|c|c|c|c|}
\hline \multirow[t]{2}{*}{$\begin{array}{l}\text { Dependent } \\
\text { Variable }\end{array}$} & \multirow[t]{2}{*}{$\begin{array}{l}\text { (I) } \\
\text { Group } \\
\text { s }\end{array}$} & \multirow[t]{2}{*}{$\begin{array}{l}(\mathrm{J}) \\
\text { Group } \\
\text { s }\end{array}$} & \multirow[t]{2}{*}{$\begin{array}{l}\text { Mean } \\
\text { Differen } \\
\text { ce }(\mathbf{I}-\mathbf{J})\end{array}$} & \multirow[t]{2}{*}{$\begin{array}{c}\text { Std. } \\
\text { Error }\end{array}$} & \multirow[t]{2}{*}{ Sig. ${ }^{b}$} & \multicolumn{2}{|c|}{$\begin{array}{l}95 \% \text { Confidence } \\
\text { Interval for } \\
\text { Difference }^{b}\end{array}$} \\
\hline & & & & & & $\begin{array}{l}\text { Lower } \\
\text { Bound }\end{array}$ & $\begin{array}{l}\text { Upper } \\
\text { Bound }\end{array}$ \\
\hline \multirow{6}{*}{$\begin{array}{l}\text { Pre-test First } \\
\text { Person Singular } \\
\text { Pronouns and } \\
\text { Possessive } \\
\text { Adjectives }\end{array}$} & Group & $\begin{array}{l}\text { Group } \\
\text { B }\end{array}$ & -.952 & .676 & .167 & -2.320 & .415 \\
\hline & A & $\begin{array}{l}\text { Group } \\
\text { C }\end{array}$ & -.452 & .676 & .508 & -1.820 & .915 \\
\hline & Group & $\begin{array}{l}\text { Group } \\
\text { A }\end{array}$ & .952 & .676 & .167 & -.415 & 2.320 \\
\hline & & $\begin{array}{l}\text { Group } \\
\text { C }\end{array}$ & .500 & .688 & .472 & -.891 & 1.891 \\
\hline & Group & $\begin{array}{l}\text { Group } \\
\text { A }\end{array}$ & .452 & .676 & .508 & -.915 & 1.820 \\
\hline & & $\begin{array}{l}\text { Group } \\
\text { B }\end{array}$ & -.500 & .688 & .472 & -1.891 & .891 \\
\hline \multirow{6}{*}{$\begin{array}{l}\text { Post-test First } \\
\text { Person Singular } \\
\text { Pronouns and } \\
\text { Possessive } \\
\text { Adjectives }\end{array}$} & Group & $\begin{array}{l}\text { Group } \\
\text { B }\end{array}$ & $-7.119^{*}$ & .614 & .000 & -8.360 & -5.878 \\
\hline & A & $\begin{array}{l}\text { Group } \\
\text { C }\end{array}$ & $-8.833^{*}$ & .614 & .000 & -10.074 & -7.592 \\
\hline & Group & $\begin{array}{l}\text { Group } \\
\text { A }\end{array}$ & $7.119^{*}$ & .614 & .000 & 5.878 & 8.360 \\
\hline & $\mathrm{B}$ & $\begin{array}{l}\text { Group } \\
\text { C }\end{array}$ & $-1.714^{*}$ & .624 & .009 & -2.976 & -.452 \\
\hline & Group & $\begin{array}{l}\text { Group } \\
\text { A }\end{array}$ & $8.833^{*}$ & .614 & .000 & 7.592 & 10.074 \\
\hline & $\mathrm{C}$ & $\begin{array}{l}\text { Group } \\
\text { B }\end{array}$ & $1.714^{*}$ & .624 & .009 & .452 & 2.976 \\
\hline
\end{tabular}

However, the results of pairwise comparison (MANOVA) obtained from the posttest indicated that the participants had utilized first -person singular and plural pronouns as well as possessive adjectives with a high frequency. There was a 
significant difference between the students in groups $\mathrm{C}$ and A ( $\mathrm{p}=.000)$. Similarly, there was a significant difference between the students in groups $\mathrm{C}$ and $\mathrm{B}(\mathrm{p}=.000)$ and $\mathrm{A}$ and $\mathrm{B}(\mathrm{p}=.000)$ on the above-mentioned measure. The results revealed that the students in group $\mathrm{C}$ used singular first person pronouns and possessive adjectives more frequently (14.50) in comparison with participants in group B (5.79) and group A (2.67). Furthermore, the students in group B used first-person singular pronouns and possessive adjectives more frequently in comparison with students in group A ( $\mathrm{p}=.000)$ (see Tables $4,6 \& 7)$.

On the other hand, the mean scores of the students of different groups regarding the numbers of plural pronoun $\mathrm{s}$ and possessive adjectives on the posttest were as follows: the students in group A, B and C used 9.73, 4.79 and .50 of the abovementioned measure, respectively. Accordingly, the participants in group A used first-person plural pronouns and possessive adjectives more frequently in comparison with students in group $\mathrm{B}(\mathrm{p}=.000)$ and group $\mathrm{C}(\mathrm{p}=.000)$. Furthermore, the students in group B used first person plural pronouns and possessive adjectives more frequently in comparison with students in group $\mathrm{C}(\mathrm{p}=.000)$ (see Tables 5, 6 $\& 7)$.

Table 5

The use of first person plural pronouns and possessive adjectives

\begin{tabular}{|c|c|c|c|c|c|c|c|}
\hline \multirow[t]{2}{*}{$\begin{array}{l}\text { Dependent } \\
\text { Variable }\end{array}$} & \multirow[t]{2}{*}{$\begin{array}{l}\text { (I) } \\
\text { Group } \\
\mathrm{s}\end{array}$} & \multirow[t]{2}{*}{$\begin{array}{l}(\mathbf{J}) \\
\text { Group } \\
\text { s }\end{array}$} & \multirow[t]{2}{*}{$\begin{array}{l}\text { Mean } \\
\text { Differen } \\
\text { ce }(\mathbf{I}-J)\end{array}$} & \multirow[t]{2}{*}{$\begin{array}{l}\text { Std. } \\
\text { Error }\end{array}$} & \multirow[t]{2}{*}{ Sig. ${ }^{b}$} & \multicolumn{2}{|c|}{$\begin{array}{l}\text { 95\% Confidence } \\
\text { Interval for } \\
\text { Difference } \\
\end{array}$} \\
\hline & & & & & & $\begin{array}{l}\text { Lower } \\
\text { Bound }\end{array}$ & $\begin{array}{l}\text { Upper } \\
\text { Bound }\end{array}$ \\
\hline \multirow{4}{*}{$\begin{array}{l}\text { Pre-test First } \\
\text { Person Plural } \\
\text { Pronouns and } \\
\text { Possessive } \\
\text { Adjectives }\end{array}$} & Group & $\begin{array}{l}\text { Group } \\
\text { B }\end{array}$ & -.100 & .301 & .742 & -.709 & .509 \\
\hline & A & $\begin{array}{l}\text { Group } \\
\mathrm{C}\end{array}$ & .043 & .301 & .888 & -.566 & .652 \\
\hline & Group & $\begin{array}{l}\text { Group } \\
\text { A }\end{array}$ & .100 & .301 & .742 & -.509 & .709 \\
\hline & B & $\begin{array}{l}\text { Group } \\
\text { C }\end{array}$ & .143 & .307 & .644 & -.477 & .762 \\
\hline
\end{tabular}




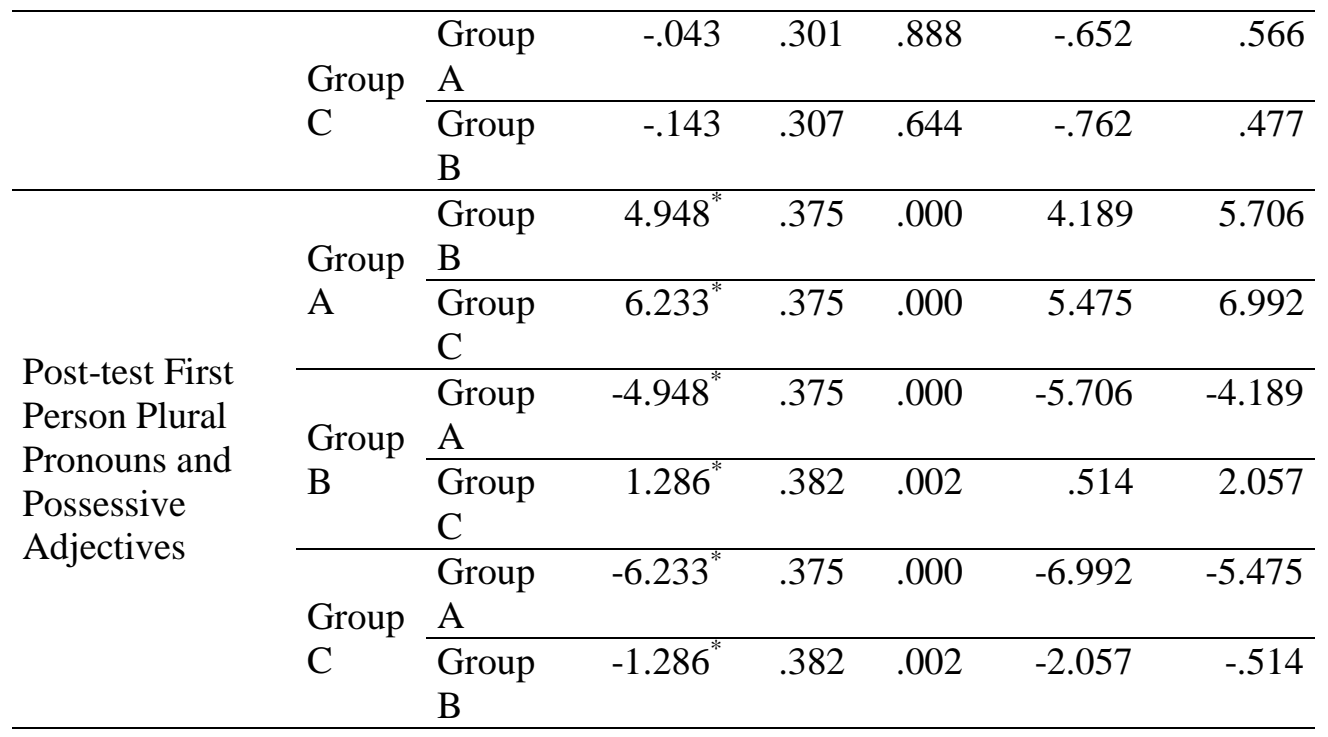

Furthermore, Table 6 and Table 7 (see Appendix I) display the frequency distribution of pronouns and possessive adjectives which the students in different groups had used on their pre-test and post-test writing tasks (see Appendix I).

\section{Discussion}

This article has attempted to demonstrate the benefits of different grouping systems to teaching Advanced Writing at the tertiary level. The findings of this study confirm the results of earlier studies in which students significantly perform better when they were engaged in group activities (see Elola \& Oskoz, 2010; Storch, 2005) or pair work (see Kim, 2008) than they performed the tasks individually. However, in contrast to some studies (see, Fernandez Dobao \& Blum, 2013; Fernandez Dobao, 2012) which assert that group activities produced significantly better results, the findings of the current study demonstrated that pair activities were more fruitful in comparison with group activities regarding the development of learners' writing abilities. In addition to different influences of various grouping systems on language learning (writing skills in this paper), the findings of this study revealed that these activities may have different effects on identity construction. 
The first research question sought to examine the efficacy of writing tasks performed individually, in pairs, or in groups. The findings of this study revealed that the instruction which the students received was fruitful and all the participants improved their writing abilities (see Table 1). The results of paired samples t-tests showed that the students in the control group (group C) could significantly improve their writing skills in comparison to their performances at the beginning of the semester. However, the results obtained from MANOVA (see Table 3) confirmed that the students in group B produced paragraphs of higher quality in comparison with those of the students in group A and group C. There was a significant difference among the students in these groups regarding the quality of writing tasks at the end of the semester. Based on the results of this study, the students in group B were successful in improving their writing tasks, because working in pairs enabled them to interact and collaborate with each other and receive feedback that pertains to appropriate word choice, tense, article, verb form pluralization, word order, mechanics, rhetorical patterns, discourse markers, etc. from their colleagues. This type of activity was beneficial and encouraged learners to improve their writing tasks before submitting the final draft. In this manner, the students who worked in pairs gained confidence and were aware that each one of them was responsible and had to put in hard efforts; consequently, they were successful in producing paragraphs of higher quality on the post-test.

The students in group A who were involved in group activities performed much better in comparison with the students in group $\mathrm{C}$ who worked individually. Students in group A had more opportunities to interact with their classmates and communicated their thoughts and ideas regarding the content and form of their writing tasks, paragraph organization, cohesion, coherence, grammar, diction, mechanics, etc. (see Fernandez Dobao \& Blum, 2013). Since the participants composed and wrote their writing tasks in groups of four and three during the semester, they had this opportunity to communicate their thoughts and ideas and produced more cohesive and coherent paragraphs. Moreover, as a result of peer collaboration and sharing their ideas on issues such as coherence, grammar, and lexicon, they were successful to apply unity and use appropriate grammatical structures and vocabulary in their writing tasks (see Nishino \& Atkinson, 2015). 
The analysis of the writing tasks of students in group A and group B illustrated that students can learn from their peers who were at the same level of language proficiency (see Fernandez Dobao \& Blum, 2013).

Nevertheless, the students in group A were not successful in producing high quality written texts in comparison with students in group B. Since they had learned to rely on other members of their group, they could not produce highquality compositions on the posttest when they had to write individually. Moreover, as Fernandez Dobao and Blum (2013) found, learners involved in group activities had more influence on certain areas of language than others. For example, students were more dependent on each other regarding the correct choice of vocabulary. On the contrary, the students in group B had a partner engaged in the process of writing in order to help the other member to produce the final draft. Additionally, as mentioned earlier, there were fewer opportunities to rely on others, since each member had to play a role equally. The findings of this study were in contrast with the results of some previous studies (see Fernandez Dobao \& Blum, 2013; Fernandez Dobao, 2012; etc.) claiming that group activities are more successful than pair activities.

On the other hand, the students in the control group (group C) who had to work individually throughout the semester could not develop their writing skills; consequently, they were not successful in producing paragraphs of high quality in comparison with the students in groups A and B. They did not receive any feedback from their peers; additionally, they did not have the opportunity to cooperate and collaborate with their classmates in order to communicate their thoughts and ideas as well as exchange information regarding form and content (see Shehade, 2011; Storch \& Wigglesworth, 2007). In reality, this is the environment of language classes. It is rarely seen in the real world that people correct each other or provide feedback on their erroneous aspects of language. Students in group A and group B benefitted from receiving feedback and comments from their peers, whereas students in group $\mathrm{C}$ were deprived of receiving feedback on issues such as grammar, diction, rhetorical patterns, cohesion, coherence, mechanics, etc. while writing their compositions.

The second research question aimed to examine the influence of different grouping system through which learners constructed various identities. The results of the students writing tasks on the pre-test regarding the use of plural and singular 
first person pronouns and possessive adjectives indicated that there was no significant difference among students in the three different groups (see Tables 4 and 5). However, the results of the post-test revealed that there were remarkable differences in the frequency distribution of first-person singular and plural pronouns and possessive adjectives among students in the three different groups.

First, the students in group A who were engaged in group activities used plural pronouns and possessive adjectives more frequently in comparison with the students in group B who worked in pairs as well as students in group C who wrote their writing tasks individually. Second, students in group B used first-person plural pronouns more frequently in comparison with the students in group C. Finally, the number of first person plural pronouns and possessive adjectives used by the students in group $\mathrm{C}$ was only seven. On the other hand, the analysis of the frequency distribution of first-person singular pronouns and possessive adjectives indicated the above-mentioned continuum in reverse direction. Students in group C used first-person singular pronouns and possessive adjectives more frequently in comparison with students in groups B and A. In subsequent turn, the students in group B used singular pronouns more frequently in comparison to students in group A.

Moreover, it is difficult to define all aspects of the concept 'identity'. From one single viewpoint, identity is a concept that is not unitary or fixed; on the contrary, it has multiple traits and facets. Identity is subject to tension and contradiction; it is constantly changing from time to time and from one space to another. From the social aspect of identity construction, identity is constructed in the course of interaction between a person and his society including other individuals and sociocultural contexts (see Burgess and Ivanic, 2010). Consequently, it is quite obvious that students in group A used first-person plural pronouns and possessive adjectives more frequently. It is a way of presenting themselves and constructing collective identities indicating a shared sense of belonging to a group.

On the other hand, students in group C (other pole of this continuum) used singular first-person pronouns and possessive adjectives more frequently. Accordingly, they constructed individual identity rather than collective identity 
(see, Melucci, 1989). Finally, the students in group B who were at the middle of this continuum used a combination of first-person singular and plural pronouns and possessive adjectives. Hence, it seems logical to conclude that the interaction between and among students is a distinguishing factor. The results of the current study demonstrated that the students in group $\mathrm{C}$ constructed individual identity because there was no interaction among them.

In contrast, the students in group A constructed collective identity. This is due to the fact that students in group A unconsciously knew that they were members of one particular group. The students in group B who were involved in pair work used a combination of singular and plural first-person pronouns as well as possessive adjectives, because there was little interaction in comparison to students in group A. On the other hand, the students in group B had more opportunities for interacting in comparison with students in group $\mathrm{C}$ who had to write individually and were deprived of any sort of collaboration and interaction among themselves. Besides, the researchers observed that the students in groups $\mathrm{B}$ and $\mathrm{C}$ used passive verbs or dummy subjects more frequently in comparison with students in group A; however, the frequency distribution of plural authorial pronouns were utilized with a high frequency by the students who were in group A.

Moreover, Wortham (2008) asserts that identity develops during the course of different time scales. The four major time scales are socio-historical, ontogenetic, mesolevel context, and microgenetic level. Socio-historical level of time scale refers to issues such as ethnicity, gender, or social class that are formed during decades. Ontogenetic level refers to the fact that people develop their exclusive and distinctive identities over months and years. Individuals approve, accept, and use sociohistorical and ontogenetic classifications over weeks, months, or years which may include distinctive activities, structures, or styles that are unique to a specific class and certain individuals. Finally, processes that occur on socio-historical, ontogenetic, and mesolevel timescales only exist empirically at the microgetic level relevant to seconds, minutes, and hours. The last two categories, namely mesolevel and microgenetic, the focus of the current study, refer to the fact that identity is constructed at the level of seconds, minutes, and hours and goes forward to the level of weeks and months. The results of the current study showed that students who were engaged in different types of activities for one semester (16 weeks), consequently, constructed identity in line with different types of activities in which they were involved. 
Finally, the results of the current study were comparable with the findings that Hyland (2002) obtained. In comparison with Hyland's study (2002), the focus of the current study was on writing tasks rather than research articles. Hyland concluded that non-native researchers writing in English may significantly downplay their roles in the research articles, since they do not utilize authorial pronoun which is an outstanding means of gaining credibility and acceptance for one's ideas. Accordingly, the role of teachers teaching writing from the beginning to advanced levels is prominent. This phenomenon, that eastern English language students (Iranian learners in this study) feel too embarrassed to enter into the text and claim the responsibility of the text will be problematic for their future academic career (see Hyland, 2002). In a similar vein, the role of different activities can be a double-edged sword. The findings of this study revealed that although the students in group A had a significantly better performance in comparison with the students in group $\mathrm{C}$, they applied more plural authorial pronouns. This implies that they consider themselves as a part of a whole and do not feel that they are much authorized to use singular pronouns when they write individually. The same generalization is true about the students who were involved in pair activities.

\section{Conclusion}

In conclusion, prewriting activities proved to be fruitful in the development of students' writing skills and, consequently, students were successful in producing high-quality written texts at the end of the semester. The students who were engaged in pair activities received high scores indicating that pair activities proved the most effective activity. Likewise, students engaged in group activities performed better than the students in group $\mathrm{C}$ working individually. The findings of the current study revealed that group activities were more effective in comparison to activities performed individually. Nevertheless, the students in Group A used authorial pronouns, plural first-person pronouns and possessive adjectives with a high frequency which implies that they unconsciously constructed collective identities. As Hyland (2002) declares, it is common in Anglo-American academic conventions to use authorial identity in order to draw the readers' attention to the role, importance, and the viewpoint of the writer. However, in most 
Asian contexts where English is a foreign language this convention is unusual in the writing performances.

On the contrary, in an environment where English is L1, writers do not use first-person singular/plural pronouns with a high frequency. It means that in most Asian countries, authors do not commonly get themselves involved in order to take responsibilities (the same identity representation was shown by the students who were in different groups at the beginning of the semester), and it is a message for the teachers to impart knowledge regarding rhetorical patterns to their students (see Hyland, 2002). Moreover, it is not sufficient for teachers to make the students familiar with the written rhetorical organizations of the second language. Most importantly, they should provide instruction on all aspects of the second language they are teaching including using singular/plural pronouns which lead to identity representations. Care should be exercised by teachers before beginning a writing class, where students are supposed to engage in different types of activities, because group activities unconsciously and gradually influence students to construct individual or collective identities and represent them in subsequent turns.

\section{Notes on contributors}

Golnar Mazdayasna is an assistant professor of Applied Linguistics at Yazd University, Yazd, Iran. Her research interests include ESP, needs assessment, genre analysis, and teaching writing and speaking skills. She has published on EAP and writing issues in national and international journals. She has also participated in many national $\&$ international conferences.

Amin Zaini obtained his MA in TEFL, from Yazd University, Yazd, Iran, in 2013. His main research interests are writing and identity. Currently, he is an EFL teacher and a guest lecturer at Hormozgan University.

\section{References}

Burgess, A., \& Ivanic, R. (2010). Written and being written: Issues of identity across timescales. Written Communication, 27 (2), 228-255.

Chastain, K. (1988). Developing second-language skills: Theory and practice. $3^{\text {rd }}$ edition. San Diego, CA: Harcourt Brace Jovanovich. 
Correa, A. D. (2011). Aspects of writing and identity. Language Sciences, 33(4), 667-671.

Elola, I. \& Oskoz, A. (2010). Collaborative writing: fostering foreign language and writing conventions development. Language Learning and Technology, 14, $51-71$.

Fernandez Dobao, A. (2012). Collaborative writing tasks in the L2 classroom: Comparing group, pair, and individual work. Journal of Second Language Writing, 21 (1), 40-58.

Fernandez Dobao, A. \& Blum, A. (2013). Collaborative writing in pairs and small groups: Learners' attitudes and perceptions. System, 41, 365-378.

Galton, M. (1990). Grouping and groupwork. In C. Rogers, \& P.Kutnick (Eds.), The social psychology of the primary school (pp. 11-30). London: Routledge.

Galton, M. J., Hargreaves, L., Comber, C., Wall, D., \& Pell, A. (1999). Inside the primary classroom: $2 o$ years on. London: Routledge.

Hua, Z. (2007). Presentation of 'self' in application letters. In Z. Hua., P. Seedhouse., L. Wei, \& V. Cook (Eds), Language learning and teaching as social Inter-Action (pp. 126-147), Great Britain: Palgrave Macmillan.

Hyland, K. (2000). Disciplinary Discourses: Social interactions in academic writing. London: Longman.

Hyland, K. (2002). Authority and invisibility: Authorial identity in academic writing. Journal of Pragmatics, 34, 1091-1112.

Ivanic, R. (1999). Writing and Identity: The discoursal construction of identity in academic writing. Benjamins, Amsterdam. 
Jacobs, H. J., Zinkgraf, S. A., Wormuth, D. R., Faye Hartfiel, V., \& Hughey, J. B. (1981). Testing ESL composition: A practical approach. Rowley, MA: Newbury House.

Kim, Y. (2008). The contribution of collaborative and individual tasks to the acquisition of L2 vocabulary. The Modern Language Journal, 92, 114-130.

Lamb-Parker, F., LeBuffe, P., Powell, G., \& Halpern, E. (2008). A strengthenbased, systematic mental health approach to support children's social and emotional development. Infants \& Young Children, 21, 45-55.

Mejia, A. M. de (2002). Power, prestige and bilingualism: International perspectives on elite bilingual education. Clevendon: Multilingual Matters.

Melucci, A. (1989). Nomads of the present: Social movements and individual needs in contemporary society. Philadelphia: Temple University Press.

Miller, J. (2003). Audible differences: ESL and social identity in schools. Clevendon: Multilingual Matters.

Nishino, T., \& Atkinson, D. (2015). Second language writing as a sociocognitive alignment. Journal of Second language Writing, 27, 37-54.

Norton, B. (2000). Identity and language learning: Gender, ethnicity and educational change. Harlow, England: Longman/Pearson Education Limited.

Olinger, A. R. (2011). Constructing identities through "discourse": Stance and interaction in collaborative college writing. Linguistics and Education, 22(3), 273-286.

Palermo, F., \& Mikulski, A. M. (2014). The role of positive peer interactions and English exposure in Spanish-speaking preschoolers' English vocabulary and letter-word skills. Early Childhood Research Quarterly, 29, 625-635.

Shehadeh, A. (2011). Effects and student perceptions of collaborative writing in L2. Journal of Second Language Writing, 20, 286-305. 
Storch, N. (2005). Collaborative writing: Product, process and students' reflections. Journal of Second Language Writing, 14, 153-173.

Storch, N., \& Wigglesworth, G. (2007). Writing tasks: Comparing individual and collaborative writing. In M. P. Garcia Mayo (Ed), Investigating tasks in Formal Language Learning, (pp.157-177), London: Multilingual Matters.

Swain, M. (2001). Integrating language and content teaching through collaborative tasks. The Canadian Modern Language Review, 58, 44-63.

Wortham, S. (2008). The objectification of identity across events. Linguistics and Education, 19, 294-311.

\section{Appendix I}

Table 6

Number of singular pronouns and possessive adjectives

\begin{tabular}{llrrr}
\hline & Groups & Mean & $\begin{array}{c}\text { Std. } \\
\text { Deviation }\end{array}$ & $\mathrm{N}$ \\
\hline \multirow{3}{*}{ Pretest } & Group & 9.33 & 2.289 & 15 \\
& A & & & \\
\cline { 2 - 5 } & Group & 10.29 & 1.204 & 14 \\
& B & & & \\
\cline { 2 - 5 } & Group & 9.79 & 1.762 & 14 \\
& C & & & \\
\cline { 2 - 5 } Total & 9.803 & 1.820 & 43 \\
\hline \multirow{4}{*}{ Posttest } & Group & 2.67 & 1.988 & 15 \\
& A & & & \\
\cline { 2 - 5 } & Group & 5.79 & 1.477 & 14 \\
& B & & & 1.401 \\
\cline { 2 - 5 } & Group & 14.50 & 14 \\
& C & & & \\
\cline { 2 - 5 } & Total & 7.65 & 4.229 & 43 \\
\hline
\end{tabular}


164 The Effect of Collaborative Prewriting Discussions on L2 Writing...

Table 7

Number of plural pronouns and possessive adjectives

\begin{tabular}{|c|c|c|c|c|}
\hline & Groups & Mean & $\begin{array}{c}\text { Std. } \\
\text { Deviation }\end{array}$ & $\mathrm{N}$ \\
\hline \multirow{4}{*}{ Pretest } & $\begin{array}{l}\text { Group } \\
\mathrm{A}\end{array}$ & .40 & .910 & 15 \\
\hline & $\begin{array}{l}\text { Group } \\
\mathrm{B}\end{array}$ & .50 & .760 & 14 \\
\hline & $\begin{array}{l}\text { Group } \\
\mathrm{C}\end{array}$ & .36 & .745 & 14 \\
\hline & Total & .42 & .794 & 43 \\
\hline \multirow{4}{*}{ Posttest } & $\begin{array}{l}\text { Group } \\
\text { A }\end{array}$ & 9.73 & 1.163 & 15 \\
\hline & $\begin{array}{l}\text { Group } \\
\text { B }\end{array}$ & 4.79 & 1.122 & 14 \\
\hline & $\begin{array}{l}\text { Group } \\
\mathrm{C}\end{array}$ & .50 & .650 & 14 \\
\hline & Total & 5.006 & 2.918 & 43 \\
\hline
\end{tabular}

